\title{
CONSERVATIVE NUTRIENT USE BY BIG-LEAF MAHOGANY (Swietenia macrophylla King) PLANTED UNDER CONTRASTING ENVIRONMENTAL CONDITIONS ${ }^{1}$
}

\author{
Ernesto Medina², Elvira Cuevas ${ }^{3}$, Ariel E. Lugo ${ }^{4}$, Evaristo Terezo ${ }^{5}$, Juan Jiménez-Osornio ${ }^{6}$, Pedro Antonio \\ Macario-Mendoza ${ }^{7}$ e Patricia Montañez ${ }^{6}$
}

\begin{abstract}
We analyzed the nutritional composition and isotope ratios ( $\mathrm{C}$ and $\mathrm{N}$ ) of big-leaf mahogany (Swietenia macrophylla King) leaves in plantations established on contrasting soils and climates in Central America (State of Quintana Roo, Yucatán, México) and South America (State of Pará, Brazil). The objective was to determine the adaptability of this species to large differences in nutrient availability and rainfall regimes. Nutrient concentrations of leaves and soils were determined spectrophotometrically, and isotope ratios were measured using mass spectrometric techniques.In Pará soils were sandier, and acidic, receiving above $2000 \mathrm{~mm}$ of rain, whereas in Quintana Roo soils were predominantly clayey, with neutral to alkaline pH due to the underlying calcareous substrate, with about $1300 \mathrm{~mm}$ of rain. Leaf area/weight ratio was similar for both sites, but leaves from Quintana Roo were significantly smaller. Average N and K concentrations of adult leaves were similar, whereas Ca concentration was only slightly lower in Pará in spite of large differences in Ca availability. Leaves from this site had slightly higher $\mathrm{P}$ and lower $\mathrm{Al}$ concentrations. Differences in water use efficiency as measured by the natural abundance of ${ }^{13} \mathrm{C}$ were negligible, the main effect of lower rainfall in Quintana Roo seemed to be a reduction in leaf area. The $\mathrm{N}$ isotope signature $\left(\delta^{15} \mathrm{~N}\right)$ was more positive in Pará than in Quintana Roo, suggesting higher denitrification rates in the former. Results reveal a calciotrophic behavior and a remarkable capacity of mahogany to compensate for large differences in soil texture and nutrient availability.
\end{abstract}

Keywords: Big-leaf mahogany; Nutrient relations; N-C isotopes.

\section{USO CONSERVATIVO DE NUTRIENTES PELO MOGNO (Swietenia macrophylla King) CULTIVADO SOB CONDIÇÕES AMBIENTAIS CONTRASTANTES}

\begin{abstract}
RESUMO - Analisou-se a composição nutricional e isotópica (C e N) de folhas de mogno (Swietenia macrophylla King) em plantações estabelecidas em solos e climas contrastantes na América Central (Quintana Roo, Yucatán, México) e na América do Sul (Pará, Brasil). O objetivo foi determinar a adaptabilidade dessa espécie para grandes diferenças na disponibilidade de nutrientes e regimes de chuva. As concentrações de nutrientes das folhas e solos foram determinadas espectrofotometricamente, e razões isotópicas foram medidas utilizando espectrometria de massa. No Pará, os solos foram mais arenosos e ácidos, recebendo acima de $2.000 \mathrm{~mm}$ de chuva, enquanto em Quintana Roo os solos foram predominantemente argilosos, com pH neutro a alcalino, devido ao substrato calcário subjacente, com cerca de $1.300 \mathrm{~mm}$ de chuva. A razão área/peso foliar foi semelhante para ambos os sítios de estudo, mas em Quintana Roo as folhas foram significativamente menores. Concentrações de N e K em folhas adultas foram semelhantes. A concentração de Ca foi apenas ligeiramente inferior no Pará, apesar das grandes diferenças na disponibilidade de Ca. Folhas desse sítio possuíam concentrações ligeiramente maiores de P e menores de Al. Diferenças na eficiência do uso da água medida pela $\delta^{13} \mathrm{C}$ foram insignificantes,
\end{abstract}

\footnotetext{
${ }^{1}$ Recebido em 15.03.2013 aceito para publicação em 14.04.2014.

${ }^{2}$ Centro de Ecología, IVIC, Venezuela and IITF USDA-Forest Service, Puerto Rico. E-mail: <medinage@gmail.com>.

${ }^{3}$ Departamento de Biología and Center for Applied Tropical Ecology and Conservation, University of Puerto Rico. E-mail: <epcuevas@gmail.com>.

${ }^{4}$ USDA-Forest Service, San Juan, Puerto Rico. E-mail: <alugo@fs.fed.us>.

${ }^{5}$ Fazenda Tramontina, Para, Brazil. E-mail <eterezo@gmail.com>.

${ }^{6}$ Departamento de Manejo de Recursos Naturales, Universidad Autónoma de Yucatán, Merida, Mexico. E-mail: <josornio@uady.mx> e <montanez@tunku.uady.mx>.

${ }^{7}$ Centro de Investigaciones de Quintana Roo, Chetumal, Quintana Roo, Mexico. E-mail: <pmacario@ecosur.qroo.mx>.
} 
e o principal efeito da menor precipitação em Quintana Roo parece ser uma redução na área foliar. Assinatura isotópica do $N\left(\delta^{15} N\right)$ foi mais positiva no Pará, que em Quintana Roo, sugerindo maiores taxas de desnitrificação no primeiro sítio de estudo. Os resultados revelaram comportamento calciotrófico e uma notável capacidade do mogno para compensar as grandes diferenças de textura e disponibilidade de nutrientes do solo.

Palavras-chave: Mogno; Nutrição mineral; Isótopos de C e N.

\section{INTRODUCTION}

Mahogany species (Swietenia spp.) produce high quality wood and have been exploited for more than 200 years from forests of South and Central America and some Caribbean islands (LAMB, 1966; WHITMORE, 2003). Swietenia macrophylla King, the big-leaf mahogany, is the main species presently involved in international trade. The natural populations of the other two species, S. mahagony and S. humilis, have been strongly depleted in their natural distribution range preventing further economic exploitation (WHITMORE, 2003). There is presently a strong movement to limit the international trade of big-leaf mahogany under the premise that the future of this species may follow the path of the Caribbean and Pacific coast species. As a result, in 2003 mahogany was incorporated in the Appendix II of CITES (Convention for International Trade of Endangered Species), requiring that all producing countries should ensure that rates and extraction procedures of mahogany are sustainable (www.cites.org).

The large geographic range of Big-leaf mahogany in South and Central America (LAMB, 1966; MAYHEW; NEWTON, 1998; GROGAN et al., 2002) suggests that the species may be tolerant to a wide range of environmental conditions. Light environment is critical for successful establishment both under natural and plantation conditions (NEGREROS-CASTILLO; MIZE, 1993; GARCÍA et al., 1993; MACARIO-MENDOZA, 1995; NEGREROS-CASTILLO; HALL, 1996; MORRIS et al., 2000; BROWN et al., 2003). However, in native forests big-leaf mahogany can survive for several years in a suppressed state in partial shade (GARCÍA et al., 1993; GULLISON et al., 1996), whereas in plantations the species regenerates without apparent restrictions (LUGO; FU, 2003). Successful establishment in the field then seems to be more a function of leaf herbivory and water availability (MAYHEW; NEWTON, 1988; GROGAN et al., 2002; BROWN et al., 2003). Within its geographic range the species thrives in a variety of soil types differing significantly in fertility (GULLISON et al., 1996; SNOOK, 1996; GROGAN etal., 2002; BROWN et al., 2003; WHITMORE, 2003). There are evidences of genetic differentiation of populations within its geographic range, underscoring the need for protection of natural habitats and development of conservation of the genotypes ex situ (NEWTON et al., 1993; LEMES et al., 2003).

Mahogany plantations have been also established in a variety of climates and soils (LAMB, 1966; MAYHEW; NEWTON, 1988; WADSWORTHet al., 2003). However, documentation of the nutritional relations of native or planted populations of big-leaf mahogany is scanty (MEDINA et al., 2003).

Plantations on different soil types and rainfall regimes may reveal how leaf chemistry is affected by differences in environmental variables. We sampled leaves and soils from big-leaf mahogany plantations established on low fertility soils of abandoned pastures in Brazil (Aurora do Pará, PA) and line plantations in mahogany natural or secondary forests in the State of Quintana Roo, Mexico. Climate, soils, and plantation methods differed markedly between these two sites. Our objective was to evaluate the adaptability of bigleaf mahogany to contrasting conditions of water and nutrient availability, using the chemical composition of leaves as indicators. In addition, we measured the ${ }^{13} \mathrm{C}$ and ${ }^{15} \mathrm{~N}$ isotopic signatures of leaves to evaluate potential differences of water use efficiency and nitrogen utilization associated with provenances, rainfall, or soil type. We hypothesized that differences in leaf chemical composition between sites would be determined by variations in growth conditions such as water and nutrient availability.

\section{MATERIALAND METHODS}

\subsection{Study areas}

The Tramontina Farm is located about $220 \mathrm{~km}$ south of Belem, (2 10’ 50" S; 47 32’0.1" W, Pará, Brazil) near the town of Aurora along the Belem-Paragominas road. The climate is tropical humid with an average rainfall 
of $2301 \mathrm{~mm}$ and temperature of $26^{\circ} \mathrm{C}$. Rainfall distribution is seasonal, being below $100 \mathrm{~mm}$ from August to November. Soils are predominantly yellow latosols with variable texture, low $\mathrm{pH}$ and low levels of organic matter, $\mathrm{N}$ and P. Big-leaf mahogany plantations were established using seeds obtained from several sources within the Amazon basin, from the states of Acre (Xapuri), Mato Grosso (Juina), Pará (Aveiro, Castelo do Sonhos, Morada do Sol, Redenção, Senador José Porfirio), and Rondônia (Ureu Wau Wau). The silvicultural activities have been undertaken within 12 years after abandonment of cattle farms. The mahogany plantations sampled were heterogeneous in age (2 to 11 years), system of planting (1. Open areas with pasture, intermixed with Schizolobium amazonicum Huber ex Ducke, 2. On abandoned pastures on early secondary succession, also intermixed with S. amazonicum Huber ex Ducke, Hymenea courbaril L., and Cordia sp., 3. Line planting in secondary forests), and soils (sandy loam, kaolinitic and lithoplinthitic soils, also with variations in fertilization treatments) (Evaristo Terezo, personal communication; see also Dias, 2008).

Several plantations were sampled in Quintana Roo, Mexico. The Ejido Laguna Om (18²9.212’N; 8858.574W) is located at $100-150 \mathrm{~m}$ above sea level, on a hilly limestone landscape (LUGO, 1999). The climate is warm sub-humid, with rains during the summer and partially in the winter, averaging $1290 \mathrm{~mm}$ per year with $26{ }^{\circ} \mathrm{C}$ average temperature. The natural vegetation in this area is a semi-evergreen forest. We sampled two areas within this locality described by Macario-Mendoza (2003):

a) The Pocito area had a mahogany plantation established in 1994 after agricultural utilization and abandonment. Mahogany trees were spaced at 5 x 5 $\mathrm{m}$ and showed little impact of insect damage.

b) The Helechal area was a 2.5 years old mixed plantation of mahogany and cedar, established within a dense, up to $1.5 \mathrm{~m}$ tall, Pteridium aquilinum (L.) Kuhn community. The treatment consisted in opening $1.5 \mathrm{~m}$ wide trails within the fern community and planting mahogany on a 5 x 5 m pattern. In this plot about $5 \%$ of the trees showed shoot borer attacks, and ranged from 1.3 to $5 \mathrm{~m}$ in height.

The Ejido Xhazil (Guadalupe area 19¹9.418N; $88^{\circ} 4.002^{\prime} \mathrm{W}$ ) belongs to a geologic formation characterized by a calcareous hardpan (LUGO, 1999). The climate is similar to that of Laguna Om, and native vegetation is also a semi-evergreen forest (MACARIO-MENDOZA,
2003). The main experimental treatments consisted in opening $1.5 \mathrm{~m}$ wide trails within a mature forest under exploitation (control), a 14 yr-old secondary vegetation (treatment 2), and a 6 yr-old secondary vegetation (treatment 3). Planting took place in 1997 along trails separated $10 \mathrm{~m}$ from each other, and the plants separated $3 \mathrm{~m}$ from each other. Plants were obtained from a nursery and averaged $30 \mathrm{~cm}$ height at planting time. At the time of sampling plants height averaged $32 \mathrm{~cm}$ in the control, $48 \mathrm{~cm}$ in treatment 2 and $354 \mathrm{~cm}$ in treatment 3. Light availability clearly determined height growth. Our field observations indicated that leaf herbivory was the most frequent cause of death.

\subsection{Processing and Analyses of Soil and Plant Samples}

At each site we collected mature ( $2^{\text {nd }}$ to $3^{\text {rd }}$ compound leaf), healthy leaves, from 3-5 randomly selected individuals. The folioles (from here on designated as leaves) were detached from the leaf rachis and drawn on paper to measure area, and subsequently dried in a ventilated oven at ca. $60{ }^{\circ} \mathrm{C}$. Leaf area and weight were used to calculate the area/weight ratios (A/W in $\mathrm{cm}^{2} / \mathrm{g}$ ). At each plot we collected also 3 samples of the upper soil layer $(0-20 \mathrm{~cm})$ using a standard 10 $\mathrm{cm}$ diameter soil corer, about $50 \mathrm{~cm}$ away from the trunk of the sampled individuals.

Soil samples from Tramontina were analyzed in the EMBRAPA laboratories in Belem, Pará, Brazil, using standardized procedures (EMBRAPA, 1998). Soils were air dried, grounded, passed through a $2 \mathrm{~mm}$ mesh sieve, and analyzed for $\mathrm{pH}$, organic matter (OM), extractable $\mathrm{P}$ and $\mathrm{K}$, and exchangeable $\mathrm{Ca}$ and $\mathrm{Al}$. The data for exchangeable elements are given on a volume basis $\left(\mathrm{dm}^{3}\right)$, therefore, they are comparable only by approximation with the usual reports on a dry weight basis.

Soils from the Quintana Roo sites were analyzed at the International Institute of Tropical Forestry (IITF, USDA-Forest Service) in Puerto Rico using standard procedures. Air dried soils samples were grounded, passed through a $0.845 \mathrm{~mm}$ sieve and analyzed for $\mathrm{C}$, $\mathrm{N}, \mathrm{P}, \mathrm{Na}, \mathrm{K}, \mathrm{Mg}, \mathrm{Ca}$, and Al using a LECO elemental analyzer (C,N) and a ICP Plasma spectrometer for the other elements (the analytical procedures are described in MEDINA et al., 2007). Available $\mathrm{P}$ and $\mathrm{K}$ were extracted with the Olsen solution (Na-bicarbonate), and exchangeable $\mathrm{Mg}$, $\mathrm{Ca}$, and $\mathrm{Al}$ were measured in $\mathrm{KCl}$ extracts.

Revista Árvore, Viçosa-MG, v.38, n.3, p.479-488, 2014 
Dried leaf samples finely grounded were analyzed for the same elements as the soils. A subsample was analyzed for stable isotopes $\left({ }^{13} \mathrm{C}\right.$ and $\left.{ }^{15} \mathrm{~N}\right)$ in the Stables Isotopes Laboratory of CENA (Universidade de São Paulo, Piracicaba, Brazil) (Tramontina samples) and the L7 isotope laboratory (University of Miami, Coral Gables, USA) (Quintana Roo samples).

\subsection{Statistical Analyses}

Soil and plant samples were submitted to a oneway analysis of variance and a posteriori tests to detect differences between means of sites and provenances (Tukey-Cramer HSD test). When variances were not homogeneous (Bartlett test) we used a Welsh test allowing for comparison of means with unequal standard deviations. Leaf dimension analysis and inter-elemental correlation in soil and leaf samples were carried out with standard regression and correlation procedures. All statistical analyses were performed using the JMP statistics package (SAS, 2002).

\section{RESULTS}

\subsection{Soils}

Textures of Tramontina soils ranged from sandy ( $>80 \%$ gross and fine sand) to medium clay (>30\% clay; $<50 \%$ sand), and were acidic, in agreement with the levels of exchangeable $\mathrm{Ca}$ and $\mathrm{Al}$ (Figure 1). As expected, $\mathrm{Ca}$ and $\mathrm{Al}$ were negatively correlated $(\mathrm{r}=0.77)$, and $\mathrm{OM}$ was positively correlated with $\mathrm{Al}(\mathrm{r}=0.74)$, suggesting that its mobility may be related to the lower $\mathrm{pH}$. Potassium was weakly positively correlated with OM, N and negatively with $\mathrm{pH}$.

In Quintana Roo soils had a clay-loam texture, were slightly alkaline, $\mathrm{pH}$ averaging 7.8 , and showed significant differences between plots in element composition (Figure 1). The samples from control plots (Xhazil forest) in Ejido Xhazil had the highest concentrations of $\mathrm{C}, \mathrm{N}$, and exchangeable $\mathrm{Mg}$. In this site concentration of organic matter (calculated by multiplying $\mathrm{C}$ concentration by 1.72), $\mathrm{N}$, and extractable $\mathrm{P}$ decreased from control to the secondary plots recovering from agricultural disturbance. Soils from Ejido Laguna Om had slightly higher $\mathrm{K}$ and extractable P. Organic matter was highly correlated with Al ( $r=0.748)$ and $\mathrm{Mg}(r=0.629)$.
Tramontina soils had very low concentrations of organic matter and $\mathrm{N}$ ranging from 7 to $26 \mathrm{~g} / \mathrm{kg}$ and 14 and $46 \mathrm{mmol} / \mathrm{kg}$, respectively (Figure 1). In Quintana Roo those values were one order of magnitude higher ranging in average from 160 to $244 \mathrm{~g} / \mathrm{kg}$ organic matter and from 500 to $900 \mathrm{mmol} / \mathrm{kg} \mathrm{N}$. The soil OM of both regions was highly correlated with $\mathrm{N}\left(\mathrm{r}^{2}\right.$ adjusted $\left.=0.979\right)$ (Figure 1).

Soil Al availability was higher in Tramontina compared to Quintana Roo in concordance with their lower $\mathrm{pH}$. However, extractable P was significantly higher in Tramontina soils.

\subsection{Leaf Dimensions}

Leaves from Fazenda Tramontina were significantly larger and heavier than those of Quintana Roo (Table 1). However, the $\mathrm{A} / \mathrm{W}$ ratios were similar in both regions, indicating a convergence in the investment in leaf area development in spite of differences in soils and climate. Leaves in Tramontina and Quintana Roo followed the same linear Area-Weight relation (Area $\mathrm{cm}^{2}=27.5+$ 72.6 Weight g; $\mathrm{r}^{2}=0.57 ; \mathrm{F}=463$, Prob $>\mathrm{F}=<0.0001$ ).

\subsection{Leaf Element Concentrations}

The leaf composition of the mahogany provenances planted in Tramontina did not reveal significant differences in any of the measured parameters, therefore, average values are included in Table 2 for comparison with samples from Quintana Roo.

Leaf nutrient concentrations in leaves from Tramontina and the sites in Quintana Roo were remarkable by their similarities. Nitrogen and $\mathrm{K}$ had similar concentrations in spite of the large differences observed for these elements in the soil samples (compare Figure 1 and Table 2). Calcium was lower in Tramontina leaves than in most Quintana Roo samples, but differences were smaller than expected considering soil Ca availability. Only P was significantly higher in the Tramontina samples, whereas S and \% Ash were significantly lower in Tramontina and in the 6-yr plot in Ejido Xhazil. As a result, the $\mathrm{N} / \mathrm{P}$ and $\mathrm{C} / \mathrm{P}$ ratios were consistently lower in Tramontina. The higher concentrations of $\mathrm{P}$ in Tramontina leaves corresponded to the measured levels of soil extractable P. Also, Al was less concentrated in Tramontina leaves in spite of its higher soil availability. The exchangeable $\mathrm{Ca} / \mathrm{Al}$ ratios in Tramontina soils was about 3 contrasting with 557 for those of Quintana Roo. The same ratios calculated for leaf values amounted to 148 for Tramontina and 78 for Quintana Roo. 

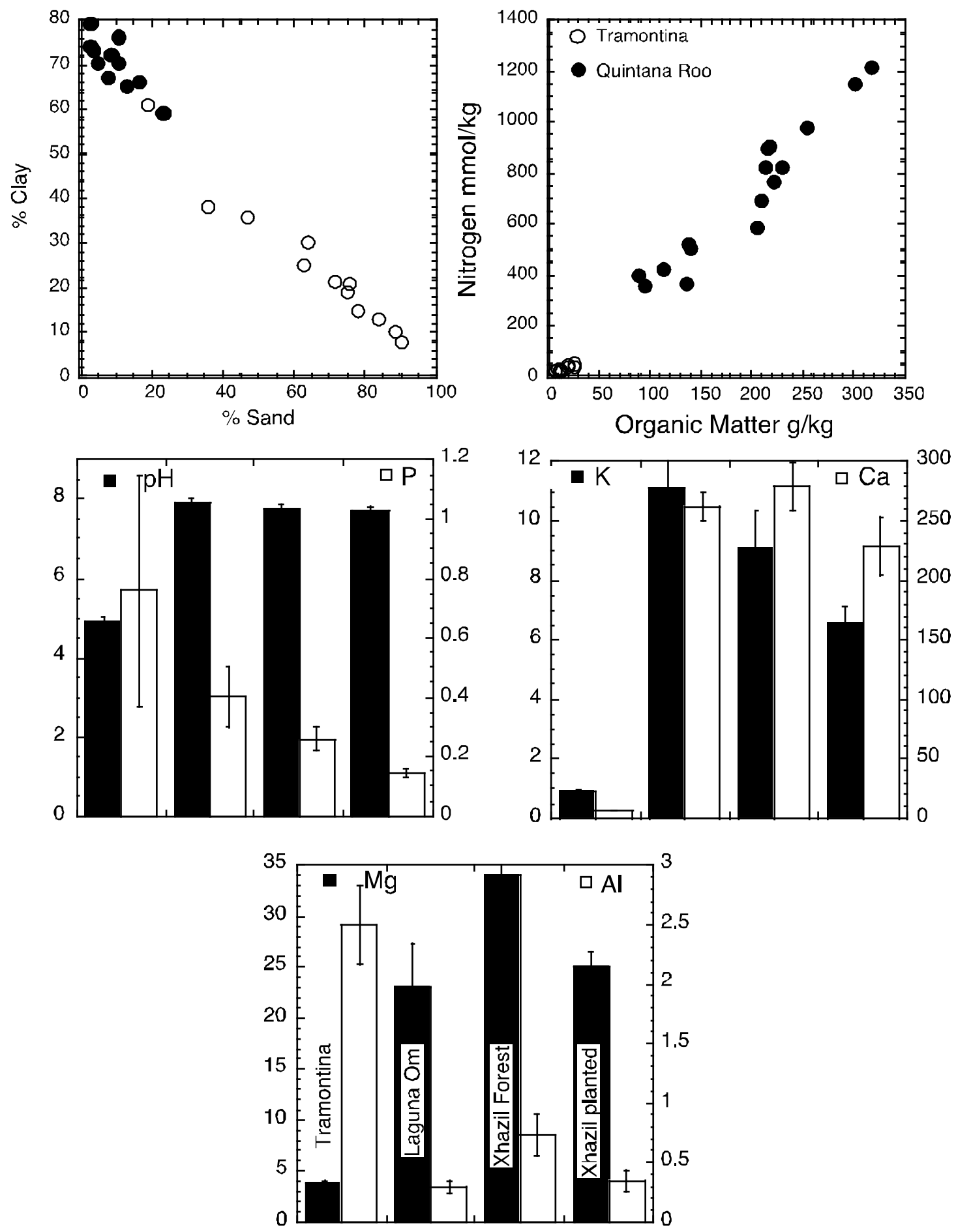

Figure 1 - Texture and chemical composition of soils sampled in Fazenda Tramontina (Pará, Brazil) and sites in Quintana Roo (Laguna Om, forest and planted plots in Xhazil). Bars in the columns indicate standard error of the mean. Figura 1 - Textura e composição química dos solos amostrados na Fazenda Tramontina (Pará, Brasil) e em Quintana Roo (Laguna Om, floresta e plantados em parcelas Xhazil). Barras em colunas indicam o erro-padrão da média. 
Table 1 - Dimensions (standard deviation) of adult leaves of big-leaf mahogany from amazon provenances planted in Fazenda Tramontina, Pará, Brazil, compared to those sampled in Quintana Roo, Mexico, sites.

Tabela 1 - Dimensões (desvio-padrão) das folhas adultas de mogno de várias proveniências amazônicas, plantadas na Fazenda Tramontina, Pará, Brasil, comparadas com plantações em Quintana Roo, México.

\begin{tabular}{lccc}
\hline Region & Tramontina & Quintana Roo & P $>|\mathbf{t}|$ \\
\hline $\mathrm{N}$ & 236 & 109 & $\mathbf{t}_{\text {test }}$ \\
Area $\left(\mathrm{cm}^{2}\right)$ & $84(37)$ & $52(26)$ & $9.2 *$ \\
Weight $(\mathrm{g})$ & $0.74(0.40)$ & $0.44(0.26)$ & $8.3 *$ \\
Area/Weight $\left(\mathrm{cm}^{2} / \mathrm{g}\right)$ & $134(69)$ & $129(42)$ & $<0.0001$ \\
\hline
\end{tabular}

Table 2 - Average concentrations of elements (mmol $/ \mathrm{kg})$ in adult leaves of big-leaf mahogany planted in Fazenda Tramontina (Pará, Brazil) and Quintana Roo, Mexico (number of samples in parenthesis).

Tabela 2 - Concentrações médias de elementos ( $\mathrm{mmol} / \mathrm{kg}$ ) em folhas adultas de mogno plantado na Fazenda Tramontina (Pará, Brasil) e em Quintana Roo, México (número de amostras entre parênteses).

\begin{tabular}{|c|c|c|c|c|c|c|c|c|}
\hline & \multirow{2}{*}{$\begin{array}{c}\text { Tramontina } \\
\text { (41) }\end{array}$} & \multicolumn{2}{|c|}{ Laguna Om } & \multicolumn{3}{|c|}{ Xhazil } & \multirow[b]{2}{*}{$\mathrm{F}$} & \multirow[b]{2}{*}{ Prob $>F$} \\
\hline & & Pocito (5) & Helechal (5) & Control (5) & 14 yr (7) & 6 yr (5) & & \\
\hline $\mathrm{C}$ & 43577 & 42212 & 43182 & 42210 & 43010 & 43846 & 6.15 & $<0.001$ \\
\hline $\mathrm{N}$ & 1218 & 1246 & 1227 & 1301 & 1265 & 1352 & 0.76 & 0.585 \\
\hline $\mathrm{S}$ & 71 & 110 & 64 & 114 & 96 & 64 & 8.68 & $<0.001$ \\
\hline $\mathrm{P}$ & 31.8 & 21.1 & 26.0 & 17.9 & 17.2 & 21.8 & 3.61 & 0.006 \\
\hline $\mathrm{K}$ & 266 & 173 & 270 & 261 & 255 & 249 & 0.558 & 0.731 \\
\hline $\mathrm{Mg}$ & 72 & 49 & 40 & 79 & 55 & 52 & 4.93 & $<0.001$ \\
\hline $\mathrm{Ca}$ & 411 & 701 & 531 & 484 & 529 & 406 & 3.29 & 0.011 \\
\hline $\mathrm{Al}$ & 2.8 & 8.7 & 6.9 & 6.3 & 6.9 & 5.1 & 31.44 & $<0.001$ \\
\hline Ash \% & 6.6 & 11.0 & 8.5 & 8.2 & 9.3 & 7.1 & 19.15 & $<0.001$ \\
\hline $\mathrm{N} / \mathrm{P}$ & 38 & 59 & 47 & 73 & 74 & 62 & & \\
\hline $\mathrm{C} / \mathrm{N}$ & 36 & 34 & 35 & 32 & 34 & 32 & & \\
\hline $\mathrm{C} / \mathrm{P}$ & 1370 & 2000 & 1660 & 2358 & 2500 & 2011 & & \\
\hline $\mathrm{Ca} / \mathrm{K}$ & 1.5 & 4.1 & 2.0 & 1.9 & 2.1 & 1.6 & & \\
\hline
\end{tabular}

\subsection{Leaf Carbon and Nitrogen Isotopic Signatures}

The carbon isotopic signatures of the provenances sampled in Tramontina were relatively homogeneous showing significant differences in $\delta^{13} \mathrm{C}$ only between Pará-Redenção and Senador José Porfírio provenances with the highest values, and Rondônia-Ureu Wau Wau with the lowest values (range $\approx 1.5 \%$, Table 3 ). Nitrogen isotope ratios showed also a similar range between the extreme values (2.2\%) but differences among provenances were significant indicating that isotopic composition of available soil $\mathrm{N}$ varied among the plots sampled.

In Quintana Roo plots were heterogeneous for both $\mathrm{C}$ and $\mathrm{N}$ isotopic signatures (Table 3). Carbon isotopic signatures were more negative in the locations with closed vegetation (Xhazil forest), and the range of variation amounted to $3 \%$. The $\mathrm{N}$ isotope signature varied significantly between plots, the range in Xhazil forest and Laguna Om amounted to $0.9 \%$.
Overall, there were not significant differences in $\delta^{13} \mathrm{C}$ signatures between the regions, but differences between $\delta^{15} \mathrm{~N}$ values were striking. All values in Tramontina were above $3 \%$, whereas in Quintana Roo they were negative (Table 3 ).

\section{DISCUSSION}

At Quintana Roo locations, soils were more fertile than those of the Fazenda Tramontina, revealing differences in soil type and land use previous to the plantation of mahogany. The organic matter concentration of Quintana Roo soils was in average more than 12 times higher than the one of Tramontina. Similarly, Quintana Roo soils had higher average N (27 times), $\mathrm{K}$ ( $\approx 10$ times) and Ca (> 20 times), but lower exchangeable Al ( $\approx 0.2)$. However, average soil extractable $\mathrm{P}$ was higher in Tramontina compared to Quintana Roo. This may be caused by immobilization of the $\mathrm{P}$ released during organic matter decomposition as Ca phosphates (MENGEL; KIRKBY, 2001). In 
Table 3 - Isotopic signatures of adult leaves from the big-leaf mahogany planted in Fazenda Tramontina (Pará, Brazil) and Quintana Roo (México). Within sites columns numbers followed by the same lower case letter, and regions averages followed by the same capital letter are not statistically different (Tukey-Cramer HSD test).

Tabela 3 - Assinaturas isotópicas de folhas adultas do mogno plantado na Fazenda Tramontina, Pará, Brasil, e Quintana Roo, México. Dentro de sites, números em colunas seguidos pela mesma letra minúscula e as médias das regiões seguidas pela mesma letra maiúscula não são estatisticamente diferentes (teste de Tukey-Cramer HSD).

\begin{tabular}{|c|c|c|c|}
\hline \multirow[t]{2}{*}{ Fazenda Tramontina Provenances } & \multicolumn{2}{|r|}{$\delta^{13} \mathrm{C} \%$} & \multirow{2}{*}{$\begin{array}{c}\delta^{15} \mathrm{~N} \% \\
\text { Mean ( } \pm \text { s.e.) }\end{array}$} \\
\hline & $\mathrm{n}$ & Mean ( \pm s.e.) & \\
\hline Acre - Xapuri & 18 & $-28.8(0.2) a b$ & $5.5(0.2) \mathrm{a}$ \\
\hline Para - Aveiro & 18 & $-29.3(0.8) a b$ & $3.7(0.2) \mathrm{c}$ \\
\hline Para - Castelo dos Sonhos & 10 & $-29.0(1.6) \mathrm{ab}$ & $5.3(0.1)$ a \\
\hline Para - Morada do Sol & 14 & $-29.3(0.9) \mathrm{ab}$ & $3.9(0.3)$ bc \\
\hline Para - Senador Jose Porfirio & 10 & $-28.5(0.3)$ a & $3.8(0.4)$ bc \\
\hline Para - Redenção & 8 & $-28.3(0.6) a$ & $4.9(0.2) a b$ \\
\hline Matto Grosso - Juina & 9 & $-28.7(0.3) a b$ & $4.0(0.2)$ bc \\
\hline \multirow[t]{4}{*}{ Rondonia - Ureu Wau Wau } & 14 & $-29.8(0.2) b$ & $3.3(0.2) \mathrm{c}$ \\
\hline & Average & $-29.1 \mathrm{~A}$ & $4.3 \mathrm{~A}$ \\
\hline & F ratio & 2.68 & 13.38 \\
\hline & Prob $>$ F & 0.01 & $<0.0001$ \\
\hline \multicolumn{4}{|l|}{ Quintana Roo Locations } \\
\hline Laguna Om & 10 & $-29.9(0.2) \mathrm{a}$ & $-0.9(0.3) a$ \\
\hline Xhazil Forest & 5 & $-32.9(0.3) b$ & $-3.0(0.3) b$ \\
\hline \multirow[t]{4}{*}{ Xhazil secondary } & 13 & $-30.5(0.4) \mathrm{a}$ & $-1.8(0.2) b$ \\
\hline & Average & $-30.7 \quad B$ & $-1.7 \mathrm{~B}$ \\
\hline & F ratio & 14.23 & 8.76 \\
\hline & Prob $>F$ & $<0.0001$ & 0.001 \\
\hline
\end{tabular}

addition, plantations in Quintana Roo were established in mature or secondary forests, with denser vegetation cover of other species besides mahogany, as a result, available $\mathrm{P}$ was more rapidly taken up by the fine root mass.

The high degree of tolerance of big-leaf mahogany to a wide range of nutrient availability is expressed in the convergence of leaf nutrient concentration levels, compensating for large differences in soil availability of N, P, Ca, and regulating Al uptake. Calcium has been shown to play an essential role in seedling growth and survival of mahogany in Para, Brazil (GROGAN et al., 2003) and considering results presented here and elsewhere (MEDINA et al., 2003), big-leaf mahogany should be considered as a calciotroph species sensu Kinzel (1983).

The ability for big-leaf mahogany to compensate for the imbalance in soil nutrient availability is revealed by the calculation of concentration ratios between locations (Tramontina/Quintana Roo) for soil and leaves respectively: 0.04 and 1 for $\mathrm{N}$; 3.5 and 1.5 for $\mathrm{P}$; 0.1 and 1.1 for $\mathrm{K}$; 0.03 and 0.8 for $\mathrm{Ca}$; and 5.7 and 0.5 for
Al. While the soils ratios varied from 0.03 to 5.7 , leaves ratios converged to 1 ( 0.5 to 1.5$)$.

Overall, elements that are strongly retranslocated before leaf shedding such as $\mathrm{N}$ and $\mathrm{P}$ showed little correlation between them and with other mineral components, whereas highly mobile $\mathrm{K}$ was negatively correlated to $\mathrm{Ca}(\mathrm{r}=-704)$ and $\mathrm{Al}(=-0.526)$. In contrast, elements that increase in concentration with leaf age such as S, Ca, and Al were significantly and positively correlated among them and with \% Ash.

Within a species leaf size and weight covary according to environmental conditions (light, water, and nutrient availability) and A/W ratios are frequently positively correlated with photosynthetic capacity (REICH et al., 1999; MEZIANE; SHIPLEY, 2001). Results showed similar A/W ratios and leaf $\mathrm{N}$ concentrations leading to the conclusion that leaves produced in both regions should have similar photosynthetic characteristics. Differences in leaf size between Pará and Quintana Roo plantations may be associated with higher water availability in Pará, whereas convergence in A/W ratios of leaves from both sites developed under high light 
suggest a compensating mechanism for differences in soil nutrient availability (KOZLOWSKI et al., 1991; MEDINA; CUEVAS, 2003).

In Tramontina the provenances Juina and Redenção showed more positive $\delta^{13} \mathrm{C}$ values, and assuming similar levels of water availability, those are the provenances with higher water use efficiency (FARQUHAR et al., 1989). $\delta^{13} \mathrm{C}$ values on Quintana Roo locations were more negative, probably a result of the relatively closed vegetation that allowed the use of ${ }^{13} \mathrm{C}$ depleted $\mathrm{CO}_{2}$ derived from soil respiration (MEDINA; MINCHIN, 1980). Similar carbon isotope signatures of sun leaves from both sites ( $\approx-29 \%$ ) indicate comparable water use efficiencies. However, lower rainfall in Quintana Roo is probably the cause of smaller leaf sizes in this site, emphasizing the importance of plasticity in leaf development to adapt to water stress.

Nitrogen isotopic ratios were not related to $\mathrm{N}$ concentration in the leaves, and differed significantly between localities. The source of this variation is probably related to mineralization processes in the soil. More positive values frequently indicate $\mathrm{a}^{15} \mathrm{~N}$ enriched mineral source, probably caused by higher levels of denitrification, and are indicative of a more open $\mathrm{N}$ cycle (MARTINELLI et al., 1999). Quintana Roo values were about 5 \% lower compared to Tramontina. This could be the result of restricted denitrification or a nitrogen source depleted in ${ }^{15} \mathrm{~N}$ (MARTINELLI et al., 1999).

\section{CONCLUSIONS}

Results showed that big-leaf mahogany plantations may be established on soils of contrasting $\mathrm{pH}$ and texture, and leaf nutrient concentrations converged to similar levels in spite of contrasting element availability in the soil. Big-leaf mahogany behaves as a calciotrophic species, showing a strong affinity for $\mathrm{Ca}$ and leaf total $\mathrm{Ca} / \mathrm{K}$ ratios $>1$ in sandy and clay soils.

The effect of seasonal drought is expressed in smaller leaf areas, whereas both $\delta^{13} \mathrm{C}$ values and leaf area/weight ratios were similar in both sites.

Natural abundance of ${ }^{15} \mathrm{~N}$ in leaves was consistently higher in the sandy soils of Tramontina Farm indicating more effective mineralization of organic matter.

\section{ACKNOWLEDGEMENTS}

The Fundación Puertoriqueña de Conservación and the International Institute of Tropical Forestry (IITF) provided funds for E.M. and E.C. to collect soils and plant samples in the field. Mary Jean Sanchez, Edwin López, Maribelis Santiago and Maysaa Ittayem of the IITF laboratory in Puerto Rico processed and analyzed the plant samples, and the soils from Quintana Roo. This research was conducted in cooperation with the University of Puerto Rico. Criticisms of two RARV reviewers improved the original version of this paper.

\section{REFERENCES}

BROWN, N.; JENNINGS, S.; CLEMENTS, T. The ecology, silviculture and biogeography of mahogany (Swietenia macrophylla): a critical review of the evidence.Perspectives Plant Ecology, Evolution and Systematics, v.6, p.37-49, 2003.

DIAS, J. D. Dinâmica do amônio e nitrato em solos consorciados com plantios de Paricá (Schizolobium Amazonicum) em Aurora do Para, Pará. 2008. 86f. (Programa de Pós-Graduação em Ciências Ambientais) - Instituto de Geociências, Universidade Federal do Pará, Museu Paraense Emílio Goeldi e EMBRAPA, Belém, 2008.

EMPRESA BRASILEIRA DE PESQUISA AGROPECUÁRIA - EMBRAPA. Análises químicas para avaliação da fertilidade do solo: métodos usados na Embrapa Solos. 1998. (Documentos, 3) (www.embrapa.br)

FARQUHAR, G. D. et al. Carbon isotope fractionation and plant water-use efficiency. In: RUNDEL, P.W.; EHLERINGER, J.R.; NAGY, K.A. (Ed.) Stable isotopes in ecological research. New York: Springer Verlag, 1989. p.21- 40.

GARCIA, C. X.; NEGREROS-CASTILLO, P.; RODRIGUEZ, S. Regeneración natural de caoba (Swietenia macrophylla King) bajo diferentes densidades de dosel. Ciencia Forestal en Mexico, v.18, n.74, p.25-43, 1993.

GROGAN, J., BARETO, P.; VERÍSSIMO,A. Mahogany in the Brazilian Amazon: Ecology and Perspectives of Management. Belém: Imazon, 2002. (on line at www.imazon.org.br) 
GROGAN, J.; ASHTON, M. S.; GALVÃO, J. Bigleaf mahogany (Swietenia macrophylla) seedling survival and growth across a topographic gradient in southeast Pará, Brazil. Forest Ecology and Management, v.186, p.311-326, 2003.

GULLISON, R. E. et al. Ecology and management of mahogany (Swietenia macrophylla King) in the Chimanes Forest, Beni, Bolivia. Botanical Journal of the Linnean Society, v.122, n.1, p.9-34, 1996.

KINZEL, H. Influence of limestone, silicates and soil $\mathrm{pH}$ on vegetation. In: LANGE, O. L. et al. (Ed.) Physiological plant ecology III. Responses to chemical and biological environment. encyclopedia of plant physiology. Berlin: Springer-Verlag, 1983. v.12. p.201-244.

KOZLOWSKI, T. K.; KRAMER, P. J.; PALLARDY, S. G. The physiological ecology of woody plants. San Diego: Academic Press, 1991.

LAMB, F. B. Mahogany of Tropical America: Its ecology and management. Ann Arbor: University of Michigan Press, 1966.

LEMES, M. R. et al. Population genetic structure of mahogany (Swietenia macrophylla King, Meliaceae) across the Brazilian Amazon, based on variation at microsatellite loci: implications for conservation. Molecular Ecology, v.12, n.11, p.2875-2883, 2003.

LUGO, J. El relieve de la península de Yucatán. In: Atlas de Procesos Territoriales de Yucatán. Mérida: UADY, 1999. p.155-162.

LUGO, A.E.; FU, S. Structure and dynamics of mahogany plantations in Puerto Rico. In: LUGO, A. E.; FIGUEROA-COLON, J. C.; ALAYÓN, M. (Ed.) Big-Leaf Mahogany: Genetic, Ecology, and Management.Ecological Studies. New York: Springer Verlag, 2003. v.159, p. 238-328,

MACARIO-MENDOZA, P. Efecto del cambio de uso del suelo sobre la selva $y$ estrategias para el manejo sustentable de la vegetación secundaria en

Quintana Roo. 2003. 150f. Tesis (Doctoral) Universidad Autónoma de Yucatán, Mérida, México, 2003.

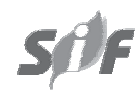

MACARIO-MENDOZA, P. A. et al. Regeneracion natural de especies arbóreas en una selva media subperennifolia perturbada por extracción forestal. Acta Botanica Mexicana, v.32, p.11-23, 1995.

MARTINELLI, L. A. et al. Nitrogen stable isotopic composition of leaves and soil: tropical versus temperate forests. Biogeochemistry, v.46, n.1, p.45-65, 1999.

MAYHEW, J. E.; NEWTON, A. C. The silviculture of mahogany. London: CABI Publishing, 1998.

MEDINA, E.; CUEVAS, E. Comparative analysis of the nutritional status of mahogany plantations in Puerto Rico. In: LUGO, A.E.; FIGUEROA-COLON, J.C.; ALAYÓN, M. (Ed.) Big-Leaf

Mahogany: genetic, ecology, and management.ecological studies. New York: Springer Verlag, 2003. v.159. p.129-145.

MEDINA, E.; MINCHIN, P. Stratification of $\delta^{13} \mathrm{C}$ values in Amazonian forests. Oecologia v.45, p.377-378, 1980.

MEDINA, E.; CUEVAS, E.; LUGO, A. E. Nutrient and salt relations of Pterocarpus officinalis L. in coastal wetlands of the Caribbean: assessment through leaf and soil analyses. Trees, v.21, p.321-327, 2007.

MEDINA, E. et al. Growth-, water-, and nutrientrelated plasticity in hybrid mahogany leaf development under contrasting light regimes. In: LUGO, A. E.; FIGUEROA-COLON, J. C.; ALAYÓN, M. (Ed.) Big-Leaf mahogany: genetic, ecology, and management.ecological studies. New York: Springer Verlag, 2003. v.159. p.146-168.

MENGEL, K.; KIRKBY, E. K. Principles of plant nutrition. 5.ed. Dordrecht: Kluwer Academic Publication, 2001.

MEZIANE, D.; SHIPLEY, B. Direct and indirect relationships between specific leaf area, leaf nitrogen and leaf gasexchange. Effects of irradiance and nutrient supply. Annals of Botany, v.88, p.915-927, 2001. 
MORRIS, M. H.; NEGREROS-CASTILLO, P.;

MIZE, C. Sowing date, shade, and irrigation affect big-leaf mahogany (Swietenia macrophylla King). Forest Ecology and Management v.132, p.173-181, 2000.

NEGREROS-CASTILLO, P.; HALL, R. First-year results of partial overstory removal and direct seeding of mahogany (Swietenia macrophylla King) in Quintana Roo, Mexico. Journal of Sustainable Forestry, v.3, n.1, p.65-76, 1996.

NEGREROS-CASTILLO, P.; MIZE, C. Effects of partial overstory removal on the natural regeneration of a tropical forest in Quintana Roo, Mexico. Forest Ecology and Management, v.58, p.259-272, 1993.

NEWTON, A. C.; LEAKEY, R. R. B.; MESEN, J. F. Genetic variation in mahoganys: its importance, utilization and conservation. Biodiversity and Conservation, v. 2, p.114-126, 1993.

REICH, P. B. et al..Generality of leaf trait relationships: a test across six biomes. Ecology, v.80, p.1955-1969, 1999.
SAS Institute INC. JMP: The Statistical Discovery Software. www.jmpdiscovery.com, 2002.

SNOOK, L. K. Catastrophic disturbance, logging and the ecology of mahogany (Swietenia macrophylla King): grounds for listing a major tropical timber species in CITES. Botanical Journal of the Linnean Society, v.122, n.1, p.35-46, 1996.

WADSWORTH, F. et al. Fifity-Nine-Year perfrmance of planted Big-Leaf Mahogany (Swietenia macrophylla King) in Puerto Rico. In: LUGO, A. E.; FIGUEROA-COLON, J. C.; ALAYÓN, M. (Ed.) Big-Leaf mahogany: genetic, ecology, and management.ecological studies. New York: Springer Verlag, 2003. v.159. p. 342-357.

WHITMORE, T. C. Mahogany: tree of the future. In: LUGO, A. E.; FIGUEROA-COLON, J. C.; ALAYÓN, M. (Ed.) Big-Leaf mahogany: genetic, ecology, and management.ecological studies. New York: Springer Verlag, 2003. v.159. p. 1-5. 